\title{
THEORY AND EVIDENCE ON EMPLOYER COLLUSION IN THE FRANCHISE SECTOR
}

\author{
Alan B. Krueger \\ Orley Ashenfelter
}

\begin{abstract}
We thank Hank Farber, Alan Manning, Bentley MacLeod, Bobby Willig and participants at the NBER Labor Studies program for helpful comments, FRANdata for providing data, and David Cho, Jun Ho Choi, Kevin DeLucam, and Victoria Angelova for research assistance. The authors are solely responsibility for any errors. The Industrial Relation Section, Princeton University, provided financial assistance. The views expressed herein are those of the authors and do not necessarily reflect the views of the National Bureau of Economic Research.
\end{abstract}

(C) 2018 by Alan B. Krueger and Orley Ashenfelter. All rights reserved. Short sections of text, not to exceed two paragraphs, may be quoted without explicit permission provided that full credit, including (C) notice, is given to the source. 
Theory and Evidence on Employer Collusion in the Franchise Sector

Alan B. Krueger and Orley Ashenfelter

October 2019

JEL No. J08,J23,J41,J42,J47,J53,J62,J63

\title{
$\underline{\text { ABSTRACT }}$
}

In this paper we study the role of covenants in franchise contracts that restrict the recruitment and hiring of employees from other units within the same franchise chain in suppressing competition for workers. Based on an analysis of 2016 Franchise Disclosure Documents, we find that "nopoaching of workers agreements" are included in a surprising 58 percent of major franchisors' contracts, including McDonald's, Burger King, Jiffy Lube and H\&R Block. The implications of these no-poaching agreements for models of oligopsony are also discussed. No-poaching agreements are more common for franchises in low-wage and high-turnover industries.

\author{
Alan B. Krueger \\ Industrial Relations Section \\ Firestone Library, Room A2H \\ Princeton University \\ Princeton, NJ 08544 \\ and NBER \\ akrueger@princeton.edu \\ Orley Ashenfelter \\ Industrial Relations Section \\ Firestone Library \\ Princeton University \\ Princeton, NJ 08544 \\ and NBER \\ c6789@princeton.edu
}




\section{Introduction}

Economists have long been interested in the extent to which employers use market power or collusive actions to suppress pay and restrict competition in the labor market. This interest extends back at least to Adam Smith (1776), who maintained that employers "are always and everywhere in a sort of tacit, but constant and uniform combination, not to raise the wages of labour above their actual rate." Smith, however, noted a critical impediment to subsequent studies of the extent of collusive behavior on the part of employers that has hindered research: "We seldom, indeed, hear of this combination, because it is the usual, and one may say, the natural state of things, which nobody ever hears of."

There is another reason why such behavior often flies below the radar screen: collusive agreements by employers to refrain from hiring each other's employees or to suppress compensation are unlawful under the Sherman Antitrust Act and potentially a criminal offense. The Department of Justice Antitrust Division and Federal Trade Commission's (2016) joint Antitrust Guidance for Human Resources Professionals plainly states, "Agreements among employers not to recruit certain employees or not to compete on terms of compensation are illegal." Although comprehensive data on the extent of collusion is unavailable, a smattering of successful high-profile antitrust cases brought against high-tech companies (e.g., Apple, Google) and film animators (e.g., The Walt Disney Company and Dreamworks), and some lower profile cases against other employers (e.g., Detroit hospitals), suggest that "gentlemen's anti-poaching and wage-fixing agreements" still exist and may be a common practice among employers.

In this paper we seek to shed light on the extent of employer collusive action to restrict competition in the labor market by examining the prevalence of covenants in franchise contracts 
that restrict the recruitment and hiring of employees from other units within the same franchise

chain. An example of such a covenant is in McDonald's standard franchise agreement:

Interference With Employment Relations of Others. During the term of this Franchise, Franchisee shall not employ or seek to employ any person who is at the time employed by McDonald's, any of its subsidiaries, or by any person who is at the time operating a McDonald's restaurant or otherwise induce, directly or indirectly, such person to leave such employment. This paragraph 14 shall not be violated if such person has left the employ of any of the foregoing parties for a period in excess of six (6) months.

A class action suit challenging the legality of this restriction was brought in Illinois under Leinani Deslandes v. McDonald's in June $2017 .^{2}$ In this case, Ms. Deslandes alleges that she was not hired by a McDonald's franchise for a job that offered higher compensation and better working conditions than her current position because her employer at the time, another nearby McDonald's franchise, refused to "release" her to change jobs.

Perhaps because such agreements have not faced a legal challenge in the past, franchise contracts provide a rare opportunity to observe and measure efforts to orchestrate behavior by employers to restrict recruitment and hiring, and thereby limit labor market competition within affiliated companies, for a comprehensive universe of major employers. Specifically, we examine data drawn from the 2016 franchise agreements used by 156 of the largest franchise chains in the U.S. Franchise Disclosure Documents (FDDs) are available for almost all major franchisors because several states require franchisors to register such information as a condition of doing business in their state. At our request, FRANdata, a research and advisory firm, reviewed FDDs for franchisors with more than 500 franchise units operating in the U.S. and identified contract language restricting the recruitment and hiring of employees from other units

\footnotetext{
${ }^{2}$ A copy of the class action complaint is available here: www.courthousen e ws.co m/wpcontent/uploads/2017/06/McDsPoaching.pdf. A similar class action suit was filed in February 2017 in California on behalfoftwo shift managers at Carl's Jr. against CKE, the parent company of Carl's Jr. and Hardees (Fry, 2017). The authors are not involved in these legal actions.
} 
within the franchise company. We find that 58 percent of major franchise chains include "noncompetitive clauses" in their franchise contract that restrict the recruitment and hiring of workers currently employed (and in some cases extending for a period after employment) by other units affiliated with the franchisor. We henceforth refer to these noncompetitive covenants as "no-poaching" agreements, to distinguish them from the type of noncompete clauses that apply to workers. Unlike employee noncompete clauses, employer no-poaching agreements operate at the employer level, and employees are not parties to such agreements or necessarily aware of them, although they can limit their opportunities.

The next section describes the franchise data in greater detail and summarizes the prevalence of no-poaching agreements by industry. Section 3 presents three theoretical models to explain the existence of such agreements: franchisor-level oligopsony; dynamic monopsony; and shifting the division of the net return on investment in specific training. A quantitative example indicates that no-poaching agreements can meaningfully alter employer market power by restricting competition for workers within franchise chains. To try to assess the relevance of the various alternative models, Section 4 provides a preliminary analysis of the predictors of the occurrence of no-poaching agreements. Although the occurrence of no-poaching agreements is not easily predicted, franchisors in industries with high labor turnover are more likely to impose no-poaching agreements than are those in low-turnover industries. No-poaching agreements are comparatively less frequent in industries with higher average wages and education levels, contrary to models that view no-poach agreements as a mechanism to encourage training investment or to protect intellectual property. 


\section{Data on Franchise "No-Poaching" Agreements}

The research and advisory firm FRANdata (based in Arlington, VA) maintains the largest database ofFDDs in the world. FRANdata obtains franchise documents from two sources: (1) states that require franchisors to register their FDDs; and (2) directly from franchisors. ${ }^{3}$ In January 2017 we contracted with FRANdata to review the 2016 FDDs for all franchisors with more than 500 franchise units operating in the U.S. and identify any contract language restricting the recruitment and hiring of employees from other units within the franchise company. Specifically, we provided FRANdata the language from the McDonald's franchise agreement (quoted above) and asked the company to review all eligible franchise contracts for similar language, and to provide us with any relevant text (and document page numbers).

FRANdata provided us a spreadsheet containing information on 156 franchise agreements. These franchise chains operated a total of 339,701 franchise and corporate units in the U.S. in 2015. In addition to information on no-poaching agreements, the file includes the year the franchisor was founded, the number of franchise and corporate units associated with the franchisor, the number of franchise units in each state, and the industry of the franchise chain.

The clauses containing restrictions on hiring and recruitment from other units in the franchise chain are sometimes listed under the heading "Noncompetition" in the contract.

Examples of three no-poaching agreements from franchise contracts are below:

Jiffy Lube: Franchisee covenants that during the term of this Agreement, Franchisee will not employ or seek to employ any person who is or within the preceding six months has been an employee of Franchisor or of any System franchisee of Franchisor, either directly or indirectly, for itself or through, on behalf of, or in conjunction with any person.

$H \& R$ Block: During the term of this Agreement, neither Franchisee nor any of Franchisee's Associates will, without H\&R Block's prior written consent: ...

\footnotetext{
${ }^{3}$ Car dealerships are not included in the FRANdata database because they utilize a special licensing business model. The vast majority of brands included in the database are business-format franchises.
} 
Solicit for employment any person who is employed by H\&R Block or by any other franchisee of H\&R Block ....

Anytime Fitness, LLC: You will not retain or hire any person employed at another Anytime Fitness center located within ten (10) miles of your Anytime Fitness Center (or who was employed at such an Anytime Fitness center within ninety (90) days of you retaining or hiring that person), to become an employee of, or provide services to your Anytime Fitness Center (or to any other business in which you have an ownership interest often percent (10\%) or more) without the consent of the owner of that other Anytime Fitness center.

Some covenants are more restrictive than others. For example, the Jiffy Lube restriction applies to all employees of the other Jiffy Lube franchisees and corporate units, and covers current workers and those who left employment of Jiffy Lube within the previous six months. The Anytime Fitness agreement, by contrast, is less restrictive, and only applies to other Anytime Fitness units within ten miles and has a shorter post-employment period (90 days). Most of the restrictions contained in the franchise agreements apply more broadly geographically than the Anytime Fitness no-poaching clause. ${ }^{4}$

The Appendix Table lists each franchise chain in the sample, whether the franchisor includes a no-poaching restriction in its contract with franchisees, the year the chain was founded, and the number of franchise and corporate units in the franchise chain. A total of 58 percent of the franchise agreements contained some restriction on franchisees' ability to recruit and hire employees away from another franchise or corporate unit in the same franchise chain. If weighted by the total number of units in the chain, the fraction with a no-poaching agreement is 55 percent. These agreements potentially affect a large number of workers.

Table la reports the number of franchise agreements with and without a no-poaching clause by industry, and Table $1 \mathrm{~b}$ reports the corresponding percentage of franchisors in each

\footnotetext{
${ }^{4}$ Some covenants allow franchisees to poach workers from other units with written consent, while others contain blanket prohibitions. Most no-poaching agreements apply to all workers while a minority are limited to managerial workers.
} 
industry with a no-poaching agreement. A chi-square test of independence indicates that there are significant differences in the prevalence of no-poaching agreements across industries, with a p-value of .001. No-poaching agreements are common in Quick Service Restaurants, FullService Restaurants, Tax Preparers (Business-Related industry), and Maintenance Service companies. They are uncommon in Hotels and Real Estate Agencies. These are both diverse sets of industries employing workers with relatively high or low skills, so it is unlikely that there is a simple or single explanation or characteristic that fully accounts for the occurrence of nopoaching restrictions in franchise contracts. Nevertheless, the fact that one can reject that the occurrence of no-poaching agreements across industries is a result of random chance suggests that industry characteristics might help predict where no-poaching agreements occur.

To determine whether no-poaching agreements have become more prevalent over time, FRANdata provided data for the 45 largest franchisors in 1996. The share of these franchisors with a no-poaching covenant increased from 35.6 percent in 1996 to 53.3 percent in 2016 (pvalue for paired t-test of no change $=0.004)$.

\section{A. Information on Employees' Franchise Employment History}

To enforce a no-poaching agreement, a prospective employer must be aware of whether a job applicant is currently, or has recently been, employed by another franchisee in the same chain. This information is commonly available in job applications, which almost universally ask applicants for their detailed job history. The McDonald's online job application goes further and 
specifically asks applicants whether they have ever worked in a McDonald's restaurant, and this question is separate and precedes the detailed employment history portion on the application. ${ }^{5}$

We examined available online job application forms for 133 of.the 156 franchise chains in our sample. Almost all of these applications collected past work experience. Forty percent of the application forms specifically asked whether the applicant has worked at the franchise chain for which he or she is applying for a job, similar to the McDonald's application. Franchise chains with a no-poaching agreement are only slightly more likely -- 42 percent versus 37 percent -- to solicit this information than are chains without a contractual no-poaching agreement. Although franchises with a no-poaching agreement are not significantly more likely to collect information on whether job applicants work for a competing employer in the same chain, this information is nonetheless widely available from applicants' work histories.

\section{Theoretical Analysis of No-Poaching Agreements}

At first blush, a basic franchise no-poaching agreement appears to fly in the face of the goal of retaining any human capital specific to the franchise company's workers. Having invested in specific skills, why compel workers to leave the franchise in order to take another job? Three models are presented below: static oligopsony; dynamic monopsony; and bargaining over the division of specific human capital.

\section{A. Unilateral Anti-Competitive Behavior}

\footnotetext{
${ }^{5}$ The complaint in the Deslandes case claims, "This [feature of the application form] helps the prospective employer easily flag current employees employed by competing McDonald's franchisees and prevents violation of the no-hire provision."
} 
One obvious explanation is that the goal of the no-poaching franchise clause is to reduce the likelihood that a worker leaves a specific franchisee outlet. By agreeing, against a franchisee's unilateral best interest, to forego hiring of other franchisee's workers, all franchisees in a chain reduce competition in their labor market and decrease the likelihood of a worker departing for another franchisee's job offer. This is equivalent to a reduction in the elasticity of labor supply faced by individual franchisees and, in the usual models of monopsony (or oligopsony, see Joan Robinson), reduces the wage relative to the marginal product oflabor. In these models, the unilateral optimality condition for hiring, where the value of the marginal product of labor (VMP) equals the wage (W), VMP-W=0 is replaced by

$$
(\mathbf{V M P}-\mathbf{W}) / \mathbf{W}=\mathbf{l} / \mathrm{tLw},
$$

where ${ }_{\mathrm{kw}}$ is the elasticity of labor supply to the firm. A lower labor supply elasticity leads to a larger gap between the marginal product of labor and the wage.

In many franchise industries, such as Quick Service Restaurants (QSR), it is natural to assume that there are literally hundreds of competitors in each labor market. If so, this suggests that the elasticity, ELw, faced by a single firm is very high and perhaps infinite, in which case there will be no gap between wage rates and marginal products. However, as we shall see, widespread use of franchise no-poaching agreements essentially reduces the number of competitive employers in a market to no more than the number of franchise companies.

More formally, ifwe assume workers are homogeneous within a franchise labor market there will be only one wage rate, which will be a function of total labor supplied to the industry in that market. With this assumption it is straightforward to adapt standard models of oligopolistic competition with multiple firms in a product market (e.g., Dansby and Willig, 1979) to a model of monopsonistic competition with multiple employers in a labor market. 
For the $i^{\text {th }}$ firm, profits are maximized when:

$$
(\mathrm{VMPi}-\mathrm{Wi}) / \mathrm{Wi}=\mathrm{Si}(1+\mathrm{ai}) / \mathrm{ELw},
$$

where $\mathrm{Si}$ is the $i^{\text {th }}$ firm's share of employment, ELw is now the industry labor supply elasticity, and ai represents the firm's perceived effect of its hiring on all other employer hiring (sometimes called an employer's conjecture). ${ }^{6}$ Defining a generalized measure of monopsony power as the summation of the squared measures of individual firm's monopsony power L[(VMPi- Wi $/ \mathrm{Wi}^{2}{ }^{2}$, Dansby and Willig show that an aggregate measure of monopsony power using (2), which is also a measure of the potential for regulatory action to improve welfare, is

$$
\mathbf{M}=(1 / \mathrm{ELw})[\boldsymbol{L} \mathbf{s} ?(\mathbf{l}+\mathbf{a i}) 2]^{112} \text {. }
$$

Notice that when $\mathrm{M}$ is large there is a prospect of improving welfare by reducing monopsony power. The ideal value ofM, where no regulatory intervention is desirable, occurs when $\mathrm{M}=\mathrm{O}$. This measure is a generalization of Robinson's equation (1), which indicates a single firm's labor market power, to the case where there are several firms. Dansby and Willig also show that various measures of employer concentration, given the market labor supply elasticity, are directly related to $\mathrm{M}$. The appropriate measure depends on what assumption is made about employer behavior (which amounts to varying assumptions about the ai).

An especially interesting case is the standard Cournot assumption about behavior, where the $\mathrm{a} i=\mathrm{O}$ except when $\mathrm{i}=\mathrm{j}$. In this case (3) simplifies to

$$
\mathbf{M} * \mathbf{H}^{112} / \mathrm{ELw},
$$

where $\mathrm{H}$ is the Hirschman-Herfindahl index of competition, $\mathrm{H}=L \mathrm{~s}$ ?. Just as with product markets, $\mathrm{H}$ is also a useful index of labor market competition, especially in cases where workers

\footnotetext{
${ }^{6}$ Formally, ai is $\mathrm{j}$; ti dL/dLi, where $\mathrm{Li}$ is the labor supply to firm $\mathrm{i}$ and $\mathrm{Li}$ is labor supply to firm $\mathrm{j}$.
} 
are either identical in production or very similar. Instead of product market shares, however, $\mathrm{H}$ should be computed from employment shares.

From this analysis it is apparent that franchise no-poaching agreements increase employer concentration and have the potential for driving a wedge between the value of a worker's marginal product and the wage. From this point of view, franchise agreements have the same anti-competitive effects in labor markets as mergers do in product markets.

\section{B. Framework for Measuring the Effect of No-Poaching Agreements on Labor Market}

\section{Competition--the Effect on $H$}

To see how this analysis may be implemented empirically, consider firms in a single industry, such as Quick Service Restaurants, in a single labor market. Assuming each restaurant is the same size and there are $\mathrm{N}$ restaurants in total, His just $1 / \mathrm{N}$ (because $\left.\mathrm{L}(1 / \mathrm{N})^{2}=1 / \mathrm{N}\right)$. In other words, the reciprocal of $\mathrm{H}$ is the number of firms. This interpretation is maintained when $\mathrm{H}$ is other than $1 / \mathrm{N}$; the reciprocal ofH in this case is a measure of how many firms of equal size it would take to generate the same Has is observed.

What is the effect of a no-poaching agreement in this framework? Franchisees are not permitted to hire from each other, which is equivalent to making the group of franchisees belonging to a chain a single employer in this labor market. To see what effect the no-poaching agreement has on labor market competition we simply assume all franchisees in the $\mathrm{i}^{\text {th }}$ chain are one company. Franchise chain i's share of employment is then ni/N, where ni is the number of restaurants belonging to franchise chain $\mathrm{i}$, and $\mathrm{His} \mathrm{H}=L(\mathrm{ni} / \mathrm{N}) 2$. A comparison of $1 / \mathrm{N}$ with $\mathrm{H}$ shows how much labor market competition has been reduced. 
In product markets there are some broadly accepted regulatory rules of thumb for $\mathrm{H}$ (which is measured with percentage market shares, i.e., 100si replaces $\mathrm{Si}$ in the calculation, so the agency measure is $\left.\mathrm{H}^{*}=\mathrm{IO}, 000 \mathrm{H}\right)$. An industry with an $\mathrm{H}^{*}$ ofless than 1,000 is generally considered competitive for purpose of merger analysis by the Federal Trade Commission or the Department of Justice. Thus in an industry with an $\mathrm{H}^{*}$ of less than 1,000 mergers that increase $\mathrm{H}^{*}$, but where $\mathrm{H}^{*}$ remains below 1,000 , would be routinely ignored. An $\mathrm{H}^{*}$ above 1,800 is considered a highly concentrated industry and mergers that increased $\mathrm{H}^{*}$ by more than 100 in such an industry would be considered problematic, and possibly subject to challenge.

A comparison of $\mathrm{N}$ and $1 / \mathrm{H}$ (i.e., ofN with $10,000 / \mathrm{H}^{*}$ ) has a useful interpretation here, as it tells us how many fewer firms there are once "no-poaching" agreements are taken into account. It seems likely that this decline in hypothetical firms will vary by location and industry. It would be fascinating to examine the correlation of wage rates with such measures.

\section{An Empirical Example: Quick Service Restaurants}

To illustrate the potential magnitude of within-franchise no-poaching agreements on competition in the labor market, we calibrate the impact of no-poaching clauses on the labor market for QSR workers in the state of Rhode Island. Rhode Island is a small, compact state and might reasonably be presumed to approximate a single labor market.

According to FRANdata, 261 individual quick service restaurants, belonging to 18 major chains, were located in Rhode Island. (This figure accords well with the 2012 Economic Census, which indicates that 265 Limited Service Restaurants in Rhode Island were part of a franchise chain.) Assuming they all have the same number of employees, the 261 quick service restaurants would have a Hirschman-Herfindahl Index $\mathbf{H}^{*}$ of 38.3, indicating a very high degree of 
competition. But if the restaurants affiliated within each franchise chain refrained from hiring each other's workers, $\mathrm{H}^{*}$ would rise to $1,678.0$, indicating a high degree of employer concentration in this labor market. ${ }^{7}$ Instead of 261 employers competing for QSR workers, this calculation suggests that there are effectively six employers (of equal size). This calibration exercise omits all the other restaurants in Rhode Island, of course, but it still suggests a potentially large impact of no-poaching agreements on the competitiveness of this labor market.

\section{The Potential for Explicit Collusion among Employers}

The analysis above assumes that employers do not explicitly collude across franchise chains in the setting of wage rates. That is, the only form of collusion considered so far is the within-franchise no-poaching agreement. However, the potential for broader collusion is clearly enhanced when no-poaching agreements are in place.

Textbook discussions of explicit collusion list several factors associated with its likelihood. Proof of collusion itself, where it is illegal as in the U.S., must typically be established by direct evidence, sometimes labeled a "smoking gun." Among the factors considered likely to promote collusion are the ease with which an agreement could be generated and monitored, the concentration of competitors (fewer firms need to agree in a more concentrated market), the profitability of collusion, and the similarity of cost conditions (see, particularly, Carlton and Perloff (2005) and Kamerschen (1979)).

A simple mechanism for collusion is quite apparent in this context. Since franchisees in a given chain have already agreed not to poach each other's workers, all that is required is to agree to not poach those of another franchise chain to implement collusion.

\footnotetext{
${ }^{7} \mathrm{We}$ find similar results if we consider the 222 quick service restaurants in the District of Columbia, an even smaller geographic area. These restaurants belong to 23 franchise chains. $\mathrm{H}^{*}$ is 45.0 if the restaurants are considered individually, and 1,666.7 ifno-poaching agreements restrict competition within franchise chains.
} 
As we showed above, the existence of franchise no-poaching agreements increases the effective concentration in the industry. This makes agreements easier to make.

The profitability of collusion depends on the elasticity of the supply of labor to the labor market in which the franchisees participate. If labor were perfectly mobile across geographic areas, labor supply to any area would be perfectly elastic. In this case, collusion within a geographic area would not be profitable, as any suppression of wages would lead workers to migrate. However, the current study oflocal geographic labor markets suggests that supply to areas the size of a Metropolitan Statistical Area or Commuting Zone are far from perfectly elastic. The recent literature finds that geographic demand shocks lead to changes in employment, as would be expected with elastic labor supply, but that demand shocks also lead to changes in wage rates, which is not consistent with highly elastic labor supply. Demand shocks that have been studied include increased imports (Autor, Dom and Hanson, 2016), the use of robots (Acemoglu and Restrepo, 2017), and others.

Finally, common costs across franchise chains make collusion easier to agree upon.

Franchise chain workers are no doubt far more substitutable, and receive far more similar wages, than workers with high education and tenure levels. In this regard minimum wages, when set too low, may have an unintended side effect. The minimum wage may become "the" wage, serving as a natural and easily enforced focal point for collusive behavior (see Shelkova, 2014).

\section{E. Dynamic Monopsony}

Another approach to modeling market power involves explicitly considering labor market dynamics. Given that labor turnover is exceptionally high in several franchise industries, and no- 
poaching agreements are specifically intended to reduce turnover, dynamic models of monopsony may be particularly applicable in this environment.

To focus on a firm's employment dynamics, let $q(w)$ represent the quit rate if the wage is wand $R(w)$ represent the number of new workers who are recruited and hired by the firm in a given period. We assume $\mathrm{q}^{\prime}(\mathrm{w})<0$ and $\mathrm{R}^{\prime}(\mathrm{w})>0$. If the employment level, denoted $\mathrm{L}(\mathrm{w})$, is constant over time, firm-level labor supply is determined by

$$
\mathrm{L}(\mathrm{w}) \mathrm{q}(\mathrm{w})=\mathrm{R}(\mathrm{w})
$$

By taking logarithms of each side of (5) and differentiating with respect tow, Card and Krueger (1995) show that the labor supply elasticity to the firm (ELw) can be expressed as the recruitment elasticity (ERw) less the quit elasticity $(E q w)$ :

$$
\varepsilon_{L w}=\varepsilon_{R w}-\varepsilon_{q w}
$$

Manning (2003) further shows that in a basic version of the Burdett and Mortensen (1998) search model, the recruitment elasticity is the negative of the quit rate elasticity, $E R w=-E q w$, soELw can be written as:

$$
\varepsilon_{L w}=\varepsilon_{R w}-\varepsilon_{q w}=-2 \varepsilon_{q w}
$$

The intuition for this result is that by raising the wage, an employer can hire some employees away from other employers, so one employer's recruit is another employer's separation. The practical implication is that we need only focus on the quit elasticity to understand the labor supply elasticity to the firm. If the quit elasticity with respect to the wage is high, firms have little monopsony power, and if it is low firms are able to pay workers less than the value of their marginal product, as per equation (1).

To understand the role of no-poaching agreements, consider the firm-level quit rate equation in a wage posting search model, such as Burdett and Mortensen(1998): 


$$
q(w)=6+11 .[1-\mathrm{F}(\mathrm{w})],
$$

where $\mathrm{O}$ is the component of the quit rate that is exogenous to wages, $\mathrm{A}$ is the job offer arrival rate, and $\mathrm{F}(\mathrm{w})$ is the distribution of wage offers. It follows that the quit elasticity with respect to the wage rate is:

$$
\begin{aligned}
& \mathbf{c}=\frac{-i l f(w) w}{q w} \quad{ }^{0+1[1-F(w))}
\end{aligned}
$$

A no-poaching agreement is intended to reduce 11. by preventing job offers from franchises in the same chain. ${ }^{8}$ To see the effect ofreducing 11.on the labor supply elasticity, note:

$$
\frac{a t: L \overline{\bar{W}}}{a 71 .} \quad 2 \frac{\mathbf{6} /(\mathbf{w}) \mathbf{w}}{\left(6+\mathrm{i}[1[1-\mathrm{F}(\mathrm{w})))_{2}-\right.}>0 .
$$

which indicates that a franchisee's labor supply elasticity is reduced if franchise chains can effectively reduce competition for workers among their franchisees. A lower labor supply elasticity, in turn, raises employer market power and enables companies to pay workers less than their contribution to productivity.

One possibility is that the process could work in reverse. Franchisees can pay belowmarket wage rates, and then discover that they have undesirably high turnover. No-poaching agreements could then be inserted in franchise contracts to reduce turnover, which facilitates a "low-wage strategy."

F Specific Human Capital, No-Poach Agreements, and Bargaining Shares

Implementing a no-poaching agreement can have several effects on the incentives for the parties to invest in human capital, and on the division of the cost of and return to investment in

\footnotetext{
${ }^{8}$ To simplify matters, we assume that the potential wage offer distribution is the same for jobs inside and outside the franchise chain.
} 
human capital. The precise effects on job training depend on assumptions regarding possible imperfections in the labor market and the nature of contracting and bargaining, but restricting workers' outside options will shift the share of the net returns from training in the direction of employers.

To start with, suppose that the labor market is characterized by perfect competition and enforceable contracts prior to the imposition of a no-poaching agreement. Becker (1964) shows that in this setup workers bear the costs and receive the returns to investment in general human capital, while firms and workers both share in the cost of and return to investment in specific human capital. Hashimoto (1981) extends this model and shows that in the extreme case where employees do not have the option to quit, employers would not share any of the cost of or return to training with employees. A no-poaching agreement reduces workers' outside options and lowers their quit rate, increasing the share of net returns to training captured by employers. Further, a franchise-wide no-poaching agreement increases the specificity of human capital investment, as training that is productive throughout the franchise chain can only be used at one franchisee under the agreement. This also has the effect of incentivizing the franchisee to bear more of the cost of training and claim more of the return that it produces. The total amount of training would be unaffected, however, as the efficient level of training would have been provided absent the no-poaching agreement, and firms have no incentives to invest in more than the efficient level even if they capture a larger share of the net return.

\section{Correlates of No-Poaching Agreements}

The theoretical discussion of no-poaching agreements above suggests various firm and industry characteristics that might help predict the utilization of such agreements. For example, 
a franchisor's share of employment in the relevant market (si) is a determinant ofmonopsony power (see equation 2). Collusion is more effective if franchisors have a larger aggregate share of employment in the relevant labor market. Dynamic monopsony models emphasize the role of turnover (and a desire to reduce turnover) as a motivation for no-poaching agreements. And models based on specific training or intellectual property suggest that no-poaching agreements would be more common in sectors with higher education and higher wages, as specific training is a complement to education and intellectual property is likely a more important feature of production in high-wage jobs.

To explore correlates of no-poaching agreements, we merged industry-level data on turnover, average wages (for hourly workers), and average years of education to the FRANdata contract sample using the January 2012, 2014 and 2016 Current Population Survey (CPS) Job Tenure Supplements based on 32 three-digit CPS industries. Turnover is measured by the new hire rate, specifically the percent of workers in the industry with a year or less of tenure, which ranged from 7.6 percent in barber shops to 39.3 percent in Eating and Drinking Establishments and 45.8 percent in Personnel Supply Services.

From the 2012 Economic Census, we merged information on the total number of establishments, and the number associated with a franchisor, in each industry to the FRANdata based on six-digit NAICS codes. We used this information to calculate each franchisor's share of the market (i.e., number of franchisor's establishments relative to total number of establishments in the industry). We also computed the share of workers in an industry employed by establishments belonging to a franchise (with both the numerator and denominator from the Economic Census), which ranged from under 2 percent in Landscaping, Plumbing, and Periodical Publishers to 73 percent inLimited Service Restaurants. Lastly, we have franchisor- 
level data on the year the franchise was founded, the number of franchise and corporate units operating in 2015, and the number of franchise outlets in each state from FDDs.

Table 2 contains a set of logit estimates where the dependent variable equals 1 if the franchise chain has a no-poaching agreement and $\mathrm{O}$ otherwise. The explanatory variables are all worker characteristics derived from the CPS at the industry level. Because the variables are highly correlated, we first enter them individually in columns 1-3, and then report a multivariate model in column $4 .{ }^{9}$ Our measures are imperfect proxies for the relevant theoretical constructs, and, in any event, the direction of causality is unclear. Consequently, this analysis is best viewed as an exploratory exercise to learn about the correlates of no-poaching agreements. With this caveat in mind, the most robust predictor in the logit equations is our measure of turnover: industries with a higher new hire rate are more likely to have a no-poaching agreement. There is little evidence that no-poaching agreements arise in industries that are more likely to utilize specific training or intellectual property, as no-poaching agreements are more prevalent in lower wage industries and education has a small and statistically insignificant relationship.

Table 3 explores the effect of franchisor and industry characteristics, such as the share of establishments in the industry represented by the franchisor and the age of the franchisor. Given the apparent importance of the new-hire rate in Table 3, that variable is also included in the models shown in columns 4 and 5. None of the characteristics of franchisors are significant predictors of the occurrence of no-poaching agreements, although the percent of employment in the industry belonging to a franchise chain (either a company-owned or franchised unit) is positive and on the margin of statistical significance at the 10 percent level $(\mathrm{t}-\mathrm{ratio}=1.61)$. When the new hire rate is added to the logit equation, however, it is the only significant predictor of no-

\footnotetext{
${ }^{9}$ The correlation between the new hire rate and mean log wage is -0.85 , the correlation between mean education and mean log wage is 0.66 , and the correlation between the new hire rate and education is -0.41 .
} 
poaching agreements and the industry franchise share becomes negative (and still statistically insignificant). Thus, this exploratory statistical analysis suggests the potential role of high turnover in franchisors' decisions to include no-poaching agreements in franchise contracts.

\section{Conclusion}

Agreements to refrain from recruiting and hiring away employees from other units in a franchise chain are common in franchise contracts. Such no-poaching agreements can limit turnover and reduce labor market competition. Although no-poaching agreements are more common in some industries (e.g., QSR) than others (e.g., Real Estate), the only variable that we have found that consistently predicts the occurrence of no-poaching agreements is labor turnover, measured by the industry-level new hire rate.

Anecdotal evidence from recent court cases suggests that at least some franchisees do abide by no-poaching agreements, but systematic evidence on the impact of no-poaching agreements on workers' pay and within-franchise job mobility is unavailable. A first order question for future research is to document whether within-franchise job-to-job transitions are lower for franchise chains that have no-poaching agreements compared with those that do not contain such agreements. For example, an audit study that varies job applicants' work histories could provide some evidence on whether franchises that are covered by no-poaching agreements are comparatively less likely to request interviews with candidates who report that they currently work for a franchise outlet within the same chain, as opposed to another employer, than are franchises that are not covered by a no-poaching agreement.

No-poaching agreements provide a rare opportunity to study efforts by employers to restrict competition. The occurrence of no-poaching agreements in franchise contracts suggests 
that, as Adam Smith (1776) predicted, many employers do try to combine to restrict competition. Together with survey evidence indicating that nearly 40 percent of U.S. workers have signed a noncompete agreement with their employer at some time during their career (Starr, Bishara and Prescott, 2017), no-poaching agreements may reduce workers' job opportunities. To the extent this practice has grown or become more effective, it might help explain a recent puzzle in the U.S. job market: unemployment has reached a 16-year low and job openings are at an all-time high, yet wage growth has remained surprisingly sluggish.

\section{A Postscript}

The first draft of this paper was circulated in the spring of 2017. A great deal has happened since then as a result of it. First, not long after the paper was circulated Alan Krueger and I were contacted by representatives of the Attorney General's Office of the State of Washington. In their view the non-poaching clauses in the franchise agreements that we revealed were in violation of the US and Washington Antitrust Laws. They promptly brought suit against many of the franchise firms listed in Appendix Table 1. Second, as a result of these law suits, by June of 201962 franchise companies had removed or abandoned the no-poach clauses from their franchise agreements. Appendix Table 2 lists the names of these companies and the dates at which their no-poach clauses were effectively removed. In principle, because this information provides the information needed for a pre/post comparison it could be used to form the basis for the design of a study intended to determine what effect, if any, these agreements may have had on worker wage rates or conditions of employment.

It was certainly not our intention to promote the law suits that resulted from the data we revealed in this paper. Nevertheless, it is instructive that the mere revelation of collusive agreements, whether legal or not, has so quickly provoked a strong response from both the antitrust authorities and the franchisors whose agreements contained these no-poach clauses.

Orley Ashenfelter, October 2019 
VI.

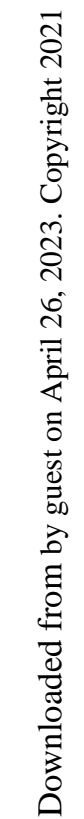




\section{References}

Acemoglu, Daron, and Pascual Restrepo. "Robots and Jobs: Evidence from US labor markets." NBER WP 23285. 2017.

Autor, David, David Dorn, and Gordon Hanson. "The China Shock: Learning from LaborMarket Adjustment to Large Changes in Trade." Annual Review of Economics 8 (2016): 205240.

Becker, Gary S. "Human capital theory." Columbia, New York (1964).

Burdett, Kenneth, and Dale T. Mortensen. "Wage differentials, employer size, and unemployment." International Economic Review (1998): 257-273.

Card, David, and Alan B. Krueger. Myth and Measurement: The New Economics of the Minimum Wage. Princeton University Press, 1995.

Carlton, Dennis and Jeffrey Perloff. Modern Industrial Organization, $4^{\text {th }}$ Edition. Pearson.

Dansby, Robert, and Robert Willig. "Industry Performance Gradient Indexes." The American Economic Review, vol. 69, no. 3, 1979, pp. 249-260.

Department of Justice Antitrust Division and Federal Trade Commission's, Antitrust Guidance for Human Resources Professionals, October 2016. Available at www.justice.gov/atr/file/903511/download.

Fry, Hannah. "Suit against Carl's Jr. parent company alleges unfair business practice to suppress wages," Los Angeles Times, Feb 8, 2017.

Hashimoto, Masanori. "Minimum wage effects on training on the job." The American Economic Review 72.5 (1982): 1070-1087.

Kamerschen, David R. "An economic approach to the detection and proof of collusion." American Business Law Journal 17.2 (1979): 193-209.

Manning, Alan. 2003. Monopsony in Motion, Princeton, NJ: Princeton University Press.

Robinson, Joan. 1969. The Economics of Imperfect Competition. $2^{\text {nd }}$ ed. London: Macmillan.

Shelkova, Natalya Y, Low-Wage Labor Markets and the Power of Suggestion (June 3, 2014).

Available at SSRN: $\underline{\text { https://ssm.com/abstract }=2478219}$

Smith, Adam. An Inquiry into the Nature and Causes of the Wealth of Nations. Originally published 1776. Reprinted Bantam Classics Edition 2003. 
Table la: Number of Franchise Chains by Industry and No-Hire Agreement

Industry

Automotive

Baked Goods

Beauty-Related

Business-Related

Child-Related

Decorating \& Home Decorating

Education-Related

Frozen Desserts

Health \& Fitness

Lodging

Maintenance Services

Personnel Services

Printing

Publications

Quick Service Restaurants

Real Estate

Restaurants (Sit-Do..

Retail Food

Retail Stores

Serv ices-General

Travel

Total

Pearson chi2(20) $=44.6$

$\frac{\text { No-Poach Agreement }}{\text { No }}$ Yes Total

$\begin{array}{rrr}2 & 4 & 6 \\ 1 & 3 & 4 \\ 4 & 4 & 8 \\ 0 & 5 & 5 \\ 2 & 1 & 3 \\ 0 & 2 & 2 \\ 1 & 0 & 1 \\ 3 & 3 & 6 \\ 5 & 6 & 11 \\ 12 & 2 & 14 \\ 5 & 8 & 13 \\ 0 & 2 & 2 \\ 2 & 0 & 2 \\ 1 & 0 & 1 \\ 8 & 32 & 40 \\ 6 & 1 & 7 \\ 0 & 5 & 5 \\ 3 & 3 & 6 \\ 7 & 4 & 11 \\ 2 & 4 & 6 \\ 1 & 2 & 3 \\ & & \\ 65 & 91 & 156\end{array}$

P-value $=0.001$ 
Table Ib: Percent with No-Hire Agreement by Industry

Industry

Automotive

Baked Goods

Beauty-Related

Business-Related

Child-Related

Decorating \& Home D..

Education-Related

Frozen Desserts

Health \& Fitness

L dging

Maintenance Services

Personnel Services

Printing

Publications

Quick Service Restaurants

Real Estate

Restaurants (Sit-Do..

Retail Food

Retail Stores

Services-General

Travel

Total

$\frac{\text { No-Poach Agreement }}{\text { No }}$

33.3

25.0

66.7

50.0

75.0

0.0

50.0

66.7

0.0

100.0

100.0

33.3

100.0

50.0

45.5

85.7

38.5

0.0

100.0

100.0

20.0

85.7

0.0

50.0

63.6

33.3

33.3

41.7
0.0

50.0

54.6

14.3

61.5

100.0

0.0

0.0

80.0

14.3

100.0

50.0

36.4

66.7

66.7

58.3 


\section{Table 2: No-Poach Clause Logit Estimates}

Average Characteristics of Workers in Industry

\begin{tabular}{|c|c|c|c|c|c|}
\hline \multirow[b]{2}{*}{ Explanatory Variable } & \multicolumn{5}{|c|}{ Has Agreement $=1$} \\
\hline & Mean [SD] & $\{1)$ & (2) & (3) & (4) \\
\hline \multirow[t]{2}{*}{ Constant } & & $-1.069^{*}$ & $-1.543^{*}$ & 3.694 & -2.311 \\
\hline & & $(0.622)$ & $(0.939)$ & (3.513) & $(4.340)$ \\
\hline \multirow[t]{2}{*}{ New Hire Rate } & 28.2 & $0.051^{* *}$ & & & $0.072^{*}$ \\
\hline & {$[9.5]$} & $(0.020)$ & & & $(0.040)$ \\
\hline \multirow[t]{2}{*}{ Mean Log Hourly Wage Rate } & 2.39 & & $-1.543^{*}$ & & 1.318 \\
\hline & {$[0.24]$} & & $(0.939)$ & & $(1.665)$ \\
\hline \multirow[t]{2}{*}{ Mean Years of Schooling } & 12.89 & & & 0.260 & -0.195 \\
\hline & [0.93] & & & $(0.260)$ & $(0.254)$ \\
\hline Pseudo R-sq & & 0.039 & 0.024 & 0.011 & 0.042 \\
\hline
\end{tabular}

Notes: Sample size is 156 franchisors. Mean of dependent variable is 0.58 .

New hire rate is percentage of workers in industry with 1 year or less of tenure. Standard errors allow for clustering at the two-digit CPS industry level. ${ }^{* *}$ statistical significant at the $5 \%$ level; * statistical significant at the $10 \%$ level. 
Table 3: No-Poach Clause Loglt Estimates

Franchise and Industry Characteristics

\begin{tabular}{|c|c|c|c|c|c|c|}
\hline \multirow[b]{2}{*}{ Explanatory Variable } & \multirow[b]{2}{*}{ Mean $[\mathrm{SD}]$} & \multicolumn{4}{|c|}{ Has Agreement=| } & \multirow[b]{2}{*}{ (5) } \\
\hline & & $(1)$ & $(2)$ & (3) & (4) & \\
\hline Constant & & $\begin{array}{c}0.238 \\
(0.298)\end{array}$ & $\begin{array}{c}0.420 \\
(0.467)\end{array}$ & $\begin{array}{l}-0.026 \\
(0.278)\end{array}$ & $\begin{array}{l}-1.687^{*} \\
(0.956)\end{array}$ & $\begin{array}{l}-1.524 \\
(\mathbf{1 . 0 4 5 )}\end{array}$ \\
\hline Age of Franchisor & $\begin{array}{l}32.4 \\
{[16.1]}\end{array}$ & $\begin{array}{c}0.003 \\
(0.008)\end{array}$ & & & & $\begin{array}{l}-0.005 \\
(0.009)\end{array}$ \\
\hline $\begin{array}{l}\text { Franchise Chain Share } \\
\text { (Percent of Establishments) }\end{array}$ & $\begin{array}{l}7.58 \\
{[14.0]}\end{array}$ & & $\begin{array}{c}-0.13 \\
(0.018)\end{array}$ & & & $\begin{array}{l}-0.002 \\
(0.002)\end{array}$ \\
\hline $\begin{array}{l}\text { Industry-Franchise Share } \\
\text { (Percent of Employment) }\end{array}$ & $\begin{array}{l}33.9 \\
{[26.7]}\end{array}$ & & & $\begin{array}{c}0.011 \\
(0.007)\end{array}$ & $\begin{array}{c}-.011 \\
(0.011)\end{array}$ & $\begin{array}{c}-.011 \\
(0.011)\end{array}$ \\
\hline New Hire Rate & $\begin{array}{l}28.2 \\
{[9.5]}\end{array}$ & & & & $\begin{array}{l}0.085^{* *} \\
(0.041)\end{array}$ & $\begin{array}{l}0.085^{* *} \\
(0.042)\end{array}$ \\
\hline Pseudo R-sq & & 0.0004 & 0.006 & 0.014 & 0.061 & 0.062 \\
\hline Sample Size & & 156 & 150 & 150 & 150 & 150 \\
\hline
\end{tabular}

Notes: Mean of dependent variable is 0.58 . Franchise chain share is total of franchisor's units as a percent of the number of establishments in 6- digit NAICS industry. Industry-Franchise Share is percent of workers in 6- digit NAICS industry employed by a franchise. New hire rate is percentage of workers in industry with 1 year or less of tenure. Standard errors allow for clustering at the two-digit CPS industry level.

** statistical significant at the 5\% level; * statistical significant at the $10 \%$ 


\section{Franchise Contract Contains No-Poaching Restriction}

\begin{tabular}{|c|c|c|}
\hline Brand & Year Founded & $\underline{201}$ \\
\hline A\&W & 1950 & 629 \\
\hline AAMCO Transmissions & 1963 & 643 \\
\hline AFC & 2002 & 3,423 \\
\hline Aaron's Sales \& Lease Ownership & 1983 & 1,905 \\
\hline Ameriprise Financial & 1999 & 6,437 \\
\hline Anago & 1991 & 1,194 \\
\hline Anytime Fitness & 2002 & 2,123 \\
\hline Applebee's Neighborhood Grill \& Bar & 1988 & 1,878 \\
\hline Arby's & 1965 & 3,214 \\
\hline Auntie Anne's & 1991 & 1,150 \\
\hline Baskin-Robbins & 1948 & 1,066 \\
\hline Batteries Plus Bulbs & 1992 & 674 \\
\hline Bricks4 Kidz & 2009 & 515 \\
\hline Budget Blinds & 1994 & 931 \\
\hline Buffalo Wlid Wings & 1991 & 1,135 \\
\hline Buildingstars & 1999 & 623 \\
\hline Burger King & & 7,127 \\
\hline Carl'.sJr. & 19.84 & 1,147 \\
\hline Cellairis & 2006 & 531 \\
\hline Church's Chicken & 1964 & 1,245 \\
\hline Cinnabon & 1990 & 750 \\
\hline Circle K & 1995 & 3,769 \\
\hline CleanNet & 1987 & 2,588 \\
\hline Comfort Keepers & 1999 & 667 \\
\hline Cruise Planners & 1994 & 2,106 \\
\hline CruiseOne & 1992 & 1,006 \\
\hline Culligan & 1945 & 560 \\
\hline Culver's ButterBurgers \& Frozen Custard & 1990 & 558 \\
\hline Curves & 1995 & 1,262 \\
\hline DaVi Nails & 2008 & 504 \\
\hline Denny's & 1963 & 1,599 \\
\hline Domino's Pizza & 1967 & 5,272 \\
\hline Dunkin' Donuts & 1955 & 7,200 \\
\hline Edible Arrangements & 2001 & 1,095 \\
\hline European Wax Center & 2006 & \\
\hline Express Employment Professionals & 1985 & 70 \\
\hline FASTSIGNS & 1986 & \\
\hline Fantastic Sams & 1995 & 1,108 \\
\hline Firehouse Subs & 1995 & \\
\hline Five Guys Burgers and Fries & 2002 & 1,215 \\
\hline Frontier Adjusters & 1959 & 688 \\
\hline GNC & 1987 & 4,304 \\
\hline H\&R Block & 1957 & 10,264 \\
\hline Hardee's & 1961 & 1,766 \\
\hline Health Mart Pharmacy & 1983 & 3,857 \\
\hline Hissho & 2013 & 827 \\
\hline Holiday Inn & 1953 & 2,547 \\
\hline Home Instead Senior Care & 1995 & 609 \\
\hline HomeVestors & 1996 & \\
\hline Hungry Howie's & 1982 & 5 \\
\hline IHOP & 1960 & 1,453 \\
\hline Jackson Hewitt Tax Service & 1986 & 6,232 \\
\hline JambaJuice & 1991 & 818 \\
\hline Jersey Mike's & 1987 & 1,044 \\
\hline Jiffy Lube & 1979 & 1,915 \\
\hline JimmyJohn's & 1993 & 2,407 \\
\hline
\end{tabular}

Franchise Contract Does Not Contain No-Poaching Restriction

Brand $\quad$ Year Founded $\quad \frac{\text { Total Units }}{\underline{2015}}$

7 -Eleven

$1964 \quad 7,812$

$1978 \quad 983$

AceHardware $\quad 1928 \quad 4,311$

Bimbo Foods BakeriesDistribution $1996 \quad 6,417$

$\begin{array}{lll}\text { Century21 } & 1972 & 2,204\end{array}$

Chem-Dry $\quad 1978 \quad 2,034$

Chester's $\quad 2004 \quad 1,020$

$\begin{array}{lll}\text { Chick-fil-A } & 1987 & 1,966\end{array}$

Coffee News

Cold Stone Creamery

Coldwell Banker

Comfort

Cornwell Quality Tools

Courtyard by Marriott

Coverall

OKI

DQ Grill \& Chill/TexasDQ

DQ Treat

Days Inn

Do It Best

ERA Real Estate

Econo Lodge

Fairfield Inn by Marriott

Fresh Healthy Vending

Godfather's Pizza

Good Neighbor Pharmacy

Great Clips

Hampton Inn by Hilton

Hardware Hank

Heaven's Best

Hilton Garden Inn

Hot Stuff Pizza

Jazzercise

KFC

Keller Williams

Kuman

Mateo Tools

Mathnasium Learning Centers

1996

1994

1982

1981

1996

1990

1985

1995

1962

1987

1972

1997

1972

1987

1989

2010

1974

2008

1983

1983

1954

1983

1990

1994

1982

1952

1987

1983

1979

2003

Merle Norman

Midas

Minuteman Press

Miracle-Ear

Motel6

Papa Murphy's Take 'N' Bake Pizza

Pop-A-Lock

Proforma

Quality Inn

RE/MAX

Regal Nails Salon \& Spa

Residence Inn by Marriott

Results! Travel

Rodeway Inn

Snap Fitness

Snap-on

Sotheby's International Realty

Subway 
Appendix Table 1: List of Franchises by Whether Contract Contains a No-Poaching Restriction - Continuation

Franchise Contract Contains No-Poaching Restriction

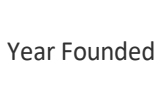

Konalce

La Quinta Inn

Lawn Doctor

Liberty Tax Service

Little Caesars

Long John Silver's

Mac Tools

Management Recruiters

Marco's Pizza

Massage Envy

McDonald's

Meineke Car Care Center

Merry Maids

Moe's Southwest Grill

Noble Roman's Pizza

Panera Bread

Papa John's

Pizza Hut

Planet Fitness

Popeyes Louisiana Kitchen

Qulznos

Rita's Ice-Custard-Happiness

Rooter-Man

ServiceMaster

Servpro

Smoothie King

Sonic

Sport Clips

The Maids

The UPS Store

Tim Hortons

Valvoline Instant Oil Change

Wendy's

Wing Stop

Zaxby's

Franchise Contract Does Not Contain No-Poaching Restriction

Total Units

IQIi

675

876

517

3,860

4,256

1,031

587

601

667

1,127

14,251

801

986

638

2,466

1,906

3,290

8,126

1,117

1,983

667

621

538

3,101

1,630

659

3,526

1,455

1,177

4,548

756

5,722
786

Notes: Data provided by FRANdata. Number of Units includes both company-owned and franchised units. 
Company

2 AAMCO

3 Anytime Fitness

4 Applebees

5 Arby's

6 Auntie Anne's

7 Dunkin Donuts Franchising LLC $\&$ its affiliate, Baskin-Robbins Franchising LLC

8 Batteries Plus LLC

9 Bonefish Grill, LLC

10 Budget Blinds, LLC

11 Buffalo Wild Wings International, Inc.

12 Burger King Corp.

13 Carl's Jr. Restaurants LLC

14 Carraba Italian Grill, LLC

15 Cajun Global LLC \& Cajun Operating Co (Church's Chicken)

16 Cinnabon Franchisor SPV LLC

17 Circle K (TMC Franchise Corp.)

18 Comfort Keepers (CK Franchising, Inc.)

19 Denny's (DFO, LLC)

20 Domino's Pizza LLC

21 Edible Arrangements, LLC

22 Einstein Bros. Bagels Franchise Corp.

23 Express Services, Inc. dba Express Employment Professionals

24 Famous Dave's of America, Inc.

25 FASTSIGNS International, Inc.

26 Firehouse of America LLC
DATE no-poach provision removed / abandoned

$3 / 1 / 18$
w/in 30-90 days of $5 / 1 / 2019$
$10 / 16 / 18$
$8 / 20 / 18$
$7 / 12 / 18$
$7 / 12 / 18$
$10 / 16 / 18$

$12 / 5 / 18$

$1 / 19 / 19$

1st Q 2018

$7 / 12 / 18$

$9 / 13 / 18$

$7 / 12 / 18$

$1 / 14 / 19$

$8 / 20 / 18$

$7 / 12 / 18$

$1 / 1 / 16$

$12 / 5 / 18$

$9 / 13 / 18$

$10 / 16 / 18$

$8 / 1 / 18$

$4 / 1 / 18$

2/15/19

$5 / 14 / 19$

$4 / 1 / 18$

$10 / 15 / 18$

AOD Para 2.2
AOD Para 2.2

$\underline{\text { Source of Info }}$

AOD Para 2.2

AOD Para 3.1.1-3.1.4

AOD Para 3.1.1-3.1.4

AOD Para 3.1.1-3.1.4

AOD Para 3.1.1-3.1.4

AOD Para 3.1.1-3.1.4

AOD Para 3.1.1-3.1.4

AOD Para 3.1.1-3.1.4

AOD Para 3.1.1-3.1.4

AOD Para 3.1.1-3.1.4

AOD Para 3.1.1-3.1.4

AOD Para 3.1.1-3.1.4

AOD Para 3.1.1-3.1.4

AOD Para 3.1.1-3.1.4

AOD Para 3.1.1-3.1.4

AOD Para 2.2- 2.3

AOD Para 3.1.1-3.1.4

AOD Para 3.1.1-3.1.4

AOD Para 3.1.1-3.1.4

AOD Para 2.2

AOD Para 3.1.1-3.1.4

AOD Para 3.1.1-3.1.4

AOD Para 2.2

AOD Para 3.1.1-3.1.4 
27 Five Guys Franchisor, LLC, an affiliate of Five Guys Enterprises, LLC

28 Frontier Adjusters, Inc.

29 General Nutrition Corp. dba GNC

30 IHOP Franchisor LLC \& IHOP Restaurants LLC

31 Jack in the Box, Inc.

32 Jackon Hewitt, Inc.

33 Jamba Juice $\mathrm{Co}$.

34 Jiffy Lube International, Inc.

35 Jimmy John's Franchisor SPV, LLC

36 L\&L Franchise, Inc.

37 La Quinta Franchising, LLC

38 Little Caesar Enterprises, Inc.

39 Maids, The (The Maids, International, Inc.)

40 Massage Envy Franchising, LLC

41 McDonald's USA, LLC

42 Meineke Franchisor SPV LLC

43 Menchie's Group, Inc.

44 Merry Maids, LP

45 Management Recruiters, International, Inc.

46 The Original Pancake House Franchising, Inc.

47 Outback Steak House of Florida, LLC

48 Panera LLC

49 Papa John's International, Inc.

50 Pizza Hut LLC

51 Planet Fitness Franchising LLC

52 Popeye's Louisiana Kitchen, Inc.

53 Qdoba Restaurant Corp.

54 Quiz Holdings LLC \& QFA Royalties LLC (Quizno's)

55 Sonic Franchising LLC
$11 / 27 / 18$

$8 / 20 / 18$

$12 / 20 / 18$

$8 / 20 / 18$

$12 / 20 / 18$

$12 / 20 / 18$

$5 / 16 / 18$

$12 / 20 / 18$

$7 / 12 / 18$

$2 / 5 / 19$

$12 / 5 / 18$

$8 / 20 / 18$

$2 / 15 / 19$

$11 / 27 / 18$

$3 / 1 / 17$

$5 / 14 / 19$

$12 / 20 / 18$

$12 / 5 / 18$

$1 / 14 / 19$

$12 / 20 / 18$

$1 / 14 / 19$

$8 / 20 / 18$

$11 / 1 / 17$

$9 / 13 / 18$

$10 / 15 / 18$

$9 / 13 / 18$

$5 / 14 / 19$

$11 / 27 / 18$

$8 / 20 / 18$
AOD Para 3.1.1-3.1.4

AOD Para 3.1.1-3.1.4

AOD Para 3.1.1-3.1.4

AOD Para 3.1.1-3.1.4

AOD Para 3.1.1-3.1.4

AOD Para 3.1.1-3.1.4

AOD Para 2.3

AOD Para 3.1.1-3.1.4

AOD Para 3.1.1-3.1.4

AOD Para 3.1.1-3.1.4

AOD Para 3.1.1-3.1.4

AOD Para 3.1.1-3.1.4

AOD Para 3.1.1-3.1.4

AOD Para 3.1.1-3.1.4

AOD Para 2.2

AOD Para 3.1.1-3.1.4

AOD Para 3.1.1-3.1.4

AOD Para 3.1.1-3.1.4

AOD Para 3.1.1-3.1.4

AOD Para 3.1.1-3.1.4

AOD Para 3.1.1-3.1.4

AOD Para 3.1.1-3.1.4

AOD Para 2.3

AOD Para 3.1.1-3.1.4

AOD Para 3.1.1-3.1.4

AOD Para 3.1.1-3.1.4

AOD Para 3.1.1-3.1.4

AOD Para 3.1.1-3.1.4

AOD Para 3.1.1-3.1.4 
Appendix Table 2: Franchisers that Abandoned No-Poach Agreements as of June 2019 - Continuation

56 Sports Clips, Inc.

$11 / 27 / 18$

57 Tim Horton's USA, Inc.

58 Valvoline Instant Oil Change Franchising, Inc.

59 Villa Pizza, LLC

60 Westside Pizza International, Inc.

61 Wingstop Restaurants, Inc.

62 Zeek's Restaurants, Inc.

Source: Washington State Attorney's Office.
$9 / 13 / 18$

$10 / 16 / 18$

$5 / 14 / 19$

$2 / 15 / 19$

$9 / 13 / 18$

$8 / 1 / 18$
AOD Para 3.1.1-3.1.4

AOD Para 3.1.1-3.1.4

AOD Para 3.1.1-3.1.4

AOD Para 3.1.1-3.1.4

AOD Para 3.1.1-3.1.4

AOD Para 3.1.1-3.1.4

AOD Para 2.3 